\title{
FLUORESCENCE STUDY OF THE PROOXIDANT ACTIVITY OF FREE FATTY ACIDS ON MARINE LIPIDS
}

Santiago P. Aubourg

Instituto de Investigaciones Marinas (CSIC)

c/ Eduardo Cabello, 6

36208-VIGO (Spain)

Phone: +34 986231930

Fax: +34 986292762

E-mail: saubourg@nautilus.iim.csic.es 


\title{
FLUORESCENCE STUDY OF THE PROOXIDANT ACTIVITY OF FREE FATTY ACIDS ON MARINE LIPIDS
}

\begin{abstract}
The free fatty acids (FFA) effect on the oxidative stability of marine lipids was studied by fluorescence assessment. Under different reaction conditions including time, temperature, FFA content and types (different chain length and unsaturation degree), FFA were made to interact in model systems with a commercial marine oil (cod liver oil) and two different fish (hake and pout) white muscles. Fluorescence assessment showed a prooxidant effect of all kinds of FFA, that increased with time, temperature and FFA content in the reaction mixtures. At $30^{\circ} \mathrm{C}$, a higher degree of oxidation was obtained in systems including the shorter chain length fatty acids (lauric and myristic) compared to systems including the longest ones (arachidic and stearic); at the same temperature, an increasing prooxidant effect was also observed with increasing degree of the fatty acid unsaturation (stearic < oleic < linoleic < linolenic). When a lower temperature $\left(-10^{\circ} \mathrm{C}\right)$ was tested, a differential prooxidant effect among fatty acids (chain length and unsaturation degree) was not observed.
\end{abstract}

Running Title: Prooxidant activity of free fatty acids

Keywords: Marine lipids, oxidation, free fatty acids, chain length, unsaturation degree, fluorescence assessment 


\section{INTRODUCTION}

During fish processing and storage, quality may decline as a result of several factors. One of the most important concerns the lipid oxidation damage $(1,2)$ because of the highly unsaturated composition of marine fatty acids (3) and the great diversity and content of different prooxidant molecules present in the fish muscle $(4,5)$. As a result, the degree of lipid deterioration during technological transformation of fish has been found to be closely related to the final product quality and shelf life $(6,7)$.

Enzymatic and non-enzymatic lipid hydrolysis was shown to occur during fish processing (8-10). Formation of free fatty acids (FFA) itself does not lead to nutritional losses. However, accumulation of FFA has been related in some extent with lack of acceptability, because FFA are known to cause detrimental effect on ATPase activity, protein solubility and relative viscosity (11), texture deterioration by interacting with proteins (12) and to be interrelated with lipid oxidation development (13).

It has been found that FFA originated from both polar and neutral lipids, although some differences have been found in the literature about the relative importance of both lipid groups depending on the process, species and temperature tested $(14,15)$. The FFA content has successfully been employed to assess fish deterioration during frozen storage (16), chilled storage (17) and ripening of anchovies (18).

Previous research based on traditional lipid oxidation indices has proved a lower oxidative stability in FFA than in their corresponding methyl esters and triglycerides $(19,20)$ and a prooxidant effect of FFA on commercial vegetable oils (21). In the present work, a rapid and accurate fluorescence assessment $(22,23)$ was applied to determine the role that FFA may play on the oxidative stability of marine lipids. The effect of 
time, temperature and varying FFA contents and types (different chain length and unsaturation degree) was examined.

\section{MATERIALS AND METHODS}

Cod liver oil (CLO) was obtained from a commercial source (Bama Geve, S. A., Barcelona, Spain). Before employing it, acid value (0.9 mg KOH/g lipids), peroxide value (1.6 meq $\mathrm{O}_{2} / \mathrm{kg}$ lipids) (24) and fatty acid composition were analysed. The following proportions (\%) of the fatty acids were obtained by gas-liquid chromatography (GLC) (25): 3.55 (C 14:0), 0.46 (C 15:0), 16.22 (C 16:0), 8.12 (C

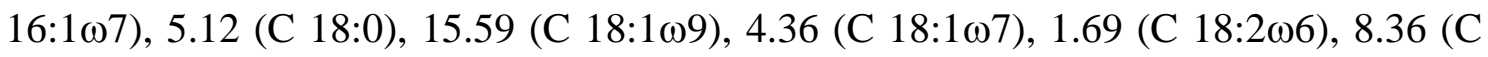

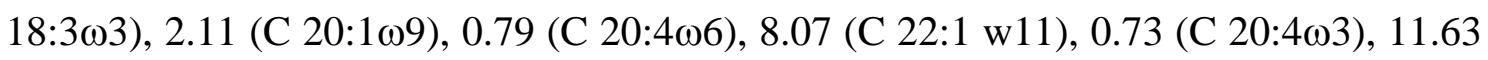

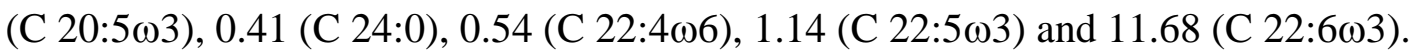

Chemicals employed (propylamine and organic solvents) were reagent grade (E. Merck, Darmstadt, Germany). Individual fatty acids employed were GLC quality ( $\geq$ $99.5 \%$ ) (Fluka, Chemie AG, Buchs, Switzerland) and their quality was checked by GLC.

\section{Cod liver oil reaction systems}

CLO reaction mixtures described bellow were incubated in all cases in triplicate in stoppered tubes in the dark at the mentioned temperature without stirring. Blank samples consisted of the individual starting reagents (CLO; propylamine, Pam; FFA), CLO + Pam and FFA + Pam mixtures under the same reaction conditions. 
Propylamine was chosen as being a common and reactive amine already employed as nucleophilic compound in this kind of model systems to interact with lipid oxidation compounds produced $(26,27)$.

Myristic acid experiments: Solutions of myristic acid (MA) $(83.3 \mathrm{mg} / 250 \mathrm{ml}$ chloroform; $1.46 \mathrm{mM}$ ) and Pam (0.987 g/500 ml aq. 86\% ethanol; $33.40 \mathrm{mM})$ were prepared. The MA solution was added to CLO portions $(0.5 \mathrm{~g})$ to obtain the following MA/CLO (w/w) proportions: $0.01 \%\left(\mathrm{MA}_{1}\right), 0.03 \%\left(\mathrm{MA}_{2}\right), 0.10 \%\left(\mathrm{MA}_{3}\right), 0.30 \%$ $\left(\mathrm{MA}_{4}\right)$, and $1.00 \%\left(\mathrm{MA}_{5}\right)$; chloroform was employed to complete each reaction system to $15 \mathrm{ml}$ volume. Then, $15 \mathrm{ml}$ of the Pam solution were added. Samples were incubated at $30^{\circ} \mathrm{C}$ and analysed at day 1, 3, 7, 14 and 25; mixtures consisting in the $1.00 \%$ proportion (MA/CLO) were also incubated at $15^{\circ} \mathrm{C}$ and $55^{\circ} \mathrm{C}$.

Different fatty acids experiments: Chloroform solutions (1.2 mM) of each fatty acid (lauric, LA; myristic, MA; palmitic, PA; stearic, SA; arachidic, AA; oleic, OA; linoleic, LnA; linolenic, LnnA) were prepared. CLO portions ( $0.5 \mathrm{~g})$ were mixed with $15 \mathrm{ml}$ of each fatty acid solution. Then, $15 \mathrm{ml}$ of the above mentioned Pam solution (33.40 mM) were added. Samples were incubated at $30^{\circ} \mathrm{C}$ and $-10^{\circ} \mathrm{C}$. Sampling was carried out at day $1,3,7,14$ and $25\left(30^{\circ} \mathrm{C}\right.$ experiment) and at month $0.5,1,2,4,6,9$ and $12\left(-10^{\circ} \mathrm{C}\right.$ experiment).

\section{Fish muscle reaction systems}

Fresh hake (Merluccius merluccius) and pout (Trisopterus luscus) were purchased 10 hr after catching; during this time the fish had been kept on ice. Upon 
arrival in the laboratory, each fish species was divided into three batches. In each batch, the white muscle was separated out and homogenised.

Minced white muscle portions (5 g) of each batch were mixed and homogenised with $9 \mathrm{ml}$ of aq. $86 \%$ ethanol. Then, $1 \mathrm{ml}$ of a MA solution $(2.5 \mathrm{~g} / 50 \mathrm{ml}$ aq. $86 \%$ ethanol) was added, so that a $1 \%$ proportion MA/fish muscle (w/w) was obtained. Samples were incubated in $30 \mathrm{ml}$ stoppered tubes in the dark at $30^{\circ} \mathrm{C}$ without stirring and sampled at 1, 3, 7, 14 and 25 days for lipid oxidation assessment.

Lipid contents of the white muscles employed were determined by the Bligh and Dyer (28) method. Mean values (g lipids/100 g muscle) were as follows: hake (0.62) and pout (0.54).

\section{Lipid oxidation assessment}

Our previous experience on fish processing (frozen and chilled storages, cooking and canning) $(22,23,29,30)$ showed that fluorescence detection of interaction compounds provided a rapid assessment of quality changes in fish products that could be more satisfactory in most cases than traditional lipid oxidation methods (conjugated dienes, peroxide value, carbonyls, thiobarbituric acid index and polyene index). Accordingly, the same fluorescence detection was employed in the present work.

Fluorescence measurements (Perkin-Elmer LS 3B) were made at 327/415 nm and 393/463 nm excitation/emission maxima. Relative fluorescences (RF) were calculated as $\mathrm{RF}=\mathrm{F} / \mathrm{F}_{\mathrm{st}}$, where $\mathrm{F}$ is the sample fluorescence at each excitation/emission maximum, and $\mathrm{F}_{\mathrm{st}}$ is the fluorescence intensity of a quinine sulphate solution ( $1 \mu \mathrm{g} / \mathrm{ml}$ in $\left.0.05 \mathrm{M} \mathrm{H}_{2} \mathrm{SO}_{4}\right)$ at the corresponding wavelength. The fluorescence ratio $(\delta \mathrm{F})$ was calculated as: $\delta \mathrm{F}=\mathrm{RF}_{393 / 463 \mathrm{~nm}} / \mathrm{RF}_{327 / 415 \mathrm{~nm}}$. 
Marine oil systems were analysed directly. Fish muscle systems were centrifuged (3000 x g for 10 minutes) and filtered. The resulting liquid part was exposed to UV light (350 nm) during $30 \mathrm{~s}$ to destroy any retinol present and was then analysed by fluorometry. Fluorescence was measured at room temperature $\left(16-18^{\circ} \mathrm{C}\right)$ with a pathlength quartz cuvette. Sensitive settings were: 5 (samples) and 0.5 (quinine sulphate standard solution).

\section{Statistical analysis}

Fluorescence ratio $(\delta \mathrm{F})$ values were subjected to the ANOVA one-way method $(\mathrm{p}<0.05)$; comparison of means after the ANOVA test were performed using a leastsquares difference (LSD) method (31). Slopes comparison of $\delta \mathrm{F}$ values obtained at different temperatures was carried out according to Glantz and Slinker (32).

\section{RESULTS}

\section{Marine oil reaction systems}

Lipid oxidation compounds (e.g., peroxides and carbonyls) produced from the CLO during the present experiments interacted with propylamine to produce fluorescent compounds $(26,33,34)$. In the absence of both kinds of compounds, no fluorescence changes were produced along the reaction time; this was the case of the individual reactant blanks (Pam, individual fatty acids and CLO) and also the mixture Pam + individual fatty acids, including different reactant ratios. Accordingly, the effect of FFA on the lipid oxidation development was evaluated by comparison with the CLO + Pam reaction system, that will be considered from now as Blank. 


\section{Effect of the free fatty acid content}

Different concentrations of a free fatty acid (MA) were made to react with the mixture CLO + Pam (Table 1). For all the MA concentrations, a progressive increase with the reaction time was recorded. Although significant differences were not obtained among all the concentrations tested, an increasing fluorescence development was observed as higher MA contents were employed. Comparison with the Blank (CLO + Pam) system lead to conclude a prooxidant effect of MA when present in the 0.10$1.00 \%$ concentration range.

\section{$\underline{\text { Effect of the reaction temperature }}$}

The effect of a free fatty acid on the oxidative damage of CLO was studied at different temperatures $\left(15^{\circ} \mathrm{C}, 30^{\circ} \mathrm{C}\right.$ and $55^{\circ} \mathrm{C}$; Table 2). Fluorescence measurement showed increasing values as long as reaction temperature and time increased. In agreement with results shown in Table 1 , the presence of MA $\left(1 \%, w / w ; A_{5}\right)$ led in all cases to significantly $(\mathrm{p}<0.05)$ higher values than the corresponding Blank system (CLO + Pam).

The fluorescence development in both reaction mixtures (Blank and $\mathrm{MA}_{5}$ ) showed a good linear correlation with the reaction time at all the temperatures tested, so that correlation coefficients were higher than 0.95 in all cases. In order to compare the rates of oxidation development at the three temperatures, a statistical comparison of the regression lines slopes was carried out (32). As a result, a faster $(\mathrm{p}<0.05)$ oxidation was obtained by temperature increase. These results corroborate the strong relationship between interaction compounds formation and temperature $(35,36)$ and the use of the fluorescence detection ( $\delta \mathrm{F}$ value) as a method of assessing lipid oxidation. 


\section{Effect of the free fatty acid type}

The prooxidant effect of different FFA types was tested at two temperatures $\left(30^{\circ} \mathrm{C}\right.$ and $\left.-10^{\circ} \mathrm{C}\right)$. All FFA were tested at the same concentration in the reaction medium (0.6 mM; Materials and Methods section), so that fatty acids comparison could be made.

The chain length effect was studied by comparing different saturated fatty acids. At $30^{\circ} \mathrm{C}$ (Figure 1), comparison with the Blank mixture showed that the presence of fatty acids led to a significantly $(\mathrm{p}<0.05)$ higher fluorescence development after day 7 in all cases. An increasing $\delta \mathrm{F}$ value was detected in the reaction system as long as the chain length of the FFA added diminished; significantly $(\mathrm{p}<0.05)$ higher values were obtained for LA and MA than for SA and AA in the latest period of the experiment (725 days). The fluorescence formation was also studied at $-10^{\circ} \mathrm{C}$ up to twelve months of reaction time (Figure 2). In this case, all FFA showed a prooxidant effect after month 2; however, no significant differences $(\mathrm{p}<0.05)$ among fatty acids were obtained during the whole experiment.

The effect of the unsaturation degree was also studied for a fatty acids series having all 18 carbon atoms. At $30^{\circ} \mathrm{C}$ (Figure 3), the presence of all FFA tested led to significantly $(\mathrm{p}<0.05)$ higher $\delta \mathrm{F}$ values than the Blank reaction mixture from day 7 till the end of the experiment. In cases of prolonged reaction times (7-25 days) an increasing $\delta \mathrm{F}$ value was detected in the reaction systems with increasing degree of unsaturation of the FFA added (SA $<$ OA $<$ LnA $<$ LnnA). Comparison was also carried out at a lower temperature $\left(-10^{\circ} \mathrm{C}\right.$; Figure 4$)$. A prooxidant effect was observed in all fatty acids analysed after two months of reaction. However, no significant differences $(p<0.05)$ were observed among the fatty acids tested along the whole experiment. 


\section{Fish muscle reaction systems}

MA was made to react with minced fish (hake and pout) muscle in model systems; its prooxidant effect on the muscle lipids was assessed by comparison with blank systems consisting of minced muscle.

The presence of this free fatty acid led to progressive increases of the $\delta \mathrm{F}$ value of the system with the reaction time in both fish species (Figure 5). Significant $(p<0.05)$ differences compared to the corresponding blank muscle samples were obtained in the two latest samplings (14 and 25 days).

Fish muscle blanks also showed a progressive increase with time of the $\delta \mathrm{F}$ value (Figure 5) as a result of interaction between the nucleophilic molecules from the muscle and the lipid oxidation compounds formed $(29,30)$.

\section{DISCUSSION}

FFA have shown a catalytic effect on lipid oxidation development when marine lipids (oil and fish muscle) were tested in model systems. This effect increased with time and temperature of the reaction mixture and with the FFA content employed. Previously, this prooxidant effect was explained on the basis of a catalytic effect of the carboxyl group on the formation of free radicals by the decomposition of hydroperoxides $(19,21)$.

Comparison of different fatty acids showed a marked increase in the catalytic effect with shorter chain length and a reaction temperature of $30^{\circ} \mathrm{C}$. This difference may be explained on the basis that the shorter the chain length, the less the positive inductive 
effect of the hydrocarbon chain (37), so that the above mentioned catalytic ability of the carboxyl group would be enhanced (stronger electrophilicity of the carbonilic carbon). This positive inductive effect of the hydrocarbon chain had also been observed when comparing the ability of different kinds of amines in producing fluorescent compounds (26). At the same time, an increasing FFA chain length would lead to an increasing steric hindrance (38) on the carboxyl group so that the catalysis ability would also be diminished.

An increasing degree of unsaturation of the FFA added has led to an increasing oxidation development in the reaction systems when the reaction temperature was $30^{\circ} \mathrm{C}$. An explanation could be a higher ability of the free fatty acid for the free radical formation as a result of delocalization of the radical formed through the double bonds system. A higher content on free radicals would lead to a higher lipid oxidation catalysis of the lipid matter present in the system (marine oil and fish muscle) and accordingly, a higher $\delta$ F value.

Reaction temperature showed to be important if differences in the prooxidant effect of different kinds of fatty acids were to be observed. At the lowest temperature tested $\left(-10^{\circ} \mathrm{C}\right)$ decomposition rate of hydroperoxides is lower than at $30^{\circ} \mathrm{C}$, so that a significantly $(\mathrm{p}<0.05)$ different catalytic effect of carboxyl groups from fatty acids with different chain length and unsaturation degree was not obtained.

Previous research related to the influence of FFA on fish damage was focused on lean fish proteins during frozen storage. A decrease in the solubility or extractability of the protein was observed when lower molecular weight fatty acids or polyunsaturated fatty acids were present $(39,40)$. In this case, the mechanism of interaction was thought to be through secondary forces (electrostatic, van der Waals, hydrogen forces) rather than through covalent bond formation. FFA would create more hydrophobic regions in 
the protein and thereby promote greater opportunities for the formation of aggregates through intermolecular interactions leading to detrimental textural changes in the fish product $(11,12)$.

FFA have been reported to be widely produced during the frozen storage of lean fish species as a result of enzyme catalysis $(8,10,22)$; during processes including high temperatures (cooking and sterilisation) a chemical hydrolysis has been detected leading to a high proportion of polyunsaturated free fatty acids $(9,25)$. Accordingly, a great attention should be payed to the FFA content and profile produced in each technological process applied to marine species.

\section{ACKNOWLEDGEMENTS}

The author acknowledges Mr. Marcos Trigo and Mr. Luis Bar for technical assistance and the European Community for financial support through the research Project FAIR-CT95-1111. 


\section{REFERENCES}

1 Hsieh R and Kinsella J, Oxidation of polyunsaturated fatty acids: Mechanisms, products, and inhibition with emphasis on fish. Adv Food Res Nutr Res 33:233341 (1989).

2 Frankel E, Review: Recent advances in lipid oxidation. J Sci Food Agric 54:495-511 (1991).

3 Ackman R, Fatty acids, in Marine biogenic lipids, fats and oils, Ed by Ackman R. CRC Press, Boca Raton, Fl (USA), Vol 1, pp 103-137 (1989).

4 German B, Zhang H and Berger R, Role of lipoxygenases in lipid oxidation in foods, in Lipid oxidation in food. Ed St. Angelo A. American Chemical Society, Washington, DC (USA), pp 74-92 (1992).

5 Harris $\mathrm{P}$ and Tall J, Rancidity in fish, in Rancidity in foods. Eds Allen J and Hamilton R. Chapman and Hall, London (UK), pp 256-272 (1994).

6 Pigott $\mathrm{G}$ and Tucker B, Science opens new horizons for marine lipids in human nutrition. Food Rev Int 3:105-138 (1987).

7 Pérez-Villarreal B and Howgate P, Deterioration of European hake (Merluccius merluccius) during frozen storage. J Sci Food Agric 55:455-469 (1991).

8 Shewfelt R, Fish muscle lipolysis- A review. J Food Biochem 5:79-100 (1981).

9 Medina I, Sacchi R and Aubourg S, A ${ }^{13}$ C-NMR study of lipid alterations during fish canning: Effect of filling medium. J Sci Food Agric 69:445-450 (1995).

10 Aubourg S, Rey-Mansilla M and Sotelo C, Differential lipid damage in various muscle zones of frozen hake (Merluccius merluccius). Z Lebensm Unters Forsch A 208:189-193 (1999). 
11 Careche $\mathrm{M}$ and Tejada $\mathrm{M}$, Hake natural actomyosin interaction with free fatty acids during frozen storage. J Sci Food Agric 64:501-507 (1994).

12 Mackie I, The effects of freezing on flesh proteins. Food Rev Intern 9:575-610 (1993).

13 Han T-J and Liston J, Lipid peroxidation and phospholipids hydrolysis in fish muscle microsomes and frozen fish. J Food Sci 52:294-299 (1987).

14 Ohshima T, Wada S and Koizumi C, Preferential enzymatic hydrolysis of phosphatidylcholine in skipjack flesh during frozen storage. Bull Jap Soc Scient Fish 50:2091-2098 (1984).

15 de Koning A, Milkovitch S and Mol T, The origin of free fatty acids formed in frozen cape hake mince (Merluccius capensis) during cold storage at $-18^{\circ} \mathrm{C} . J$ Sci Food Agric 39:79-84 (1987).

16 de Koning A and Mol T, Quantitative quality tests for frozen fish: Soluble protein and free fatty acid content as quality criteria for hake (Merluccius merluccius) stored at $-18^{\circ}$ C. J Sci Food Agric 54:449-458 (1991).

17 Barassi C, Pécora R, Roldán H and Trucco R, Total, non-volatile free fatty acids as a freshness index for hake (Merluccius hubbsi) stored in ice. J Sci Food Agric 38:373-377 (1987).

18 Roldán H, Barassi C and Trucco R, Increase on free fatty acids during ripening of anchovies (Engraulis anchoita). J Food Technol 20:581-585 (1985).

19 Miyashita K and Takagi T, Study on the oxidative rate and prooxidant activity of free fatty acids. J Am Oil Chem Soc 63:1380-1384 (1986).

20 Labuza T, Kinetics of lipid oxidation in foods. CRC Crit Rev Food Technol 2:355405 (1971). 
21 Yoshida H, Kondo I and Kajimoto G, Participation of free fatty acids in the oxidation of purified soybean oil during microwave heating. J Am Oil Chem Soc 69:1136-1140 (1992).

22 Aubourg S and Medina I, Influence of storage time and temperature on lipid deterioration during cod (Gadus morhua) and haddock (Melanogramus aeglefinus) frozen storage. J Sci Food Agric 79:1943-1948 (1999).

23 Aubourg S, Medina I and Gallardo J, Quality assessment of blue whiting (Micromesistius poutassou) during chilled storage by monitoring lipid damages. J Agric Food Chem 46:3662-3666 (1998).

24 Williams K, Oils, fats and fatty foods. Their practical examination. $3^{\text {rd }}$ edn J \& A Churchill Ltd, London (UK), pp 53-54, 107-108 (1950).

25 Aubourg S, Medina I and Pérez-Martín R, Polyunsaturated fatty acids in tuna phospholipids: Distribution in the sn-2 location and changes during cooking. $J$ Agric Food Chem 44:585-589 (1996).

26 Aubourg S and Gallardo J, Fluorescence changes in amine model systems related to fish deterioration. Int J Food Sci Technol 32:153-158 (1997).

27 Aubourg S, Influence of formaldehyde in the formation of fluorescence related to fish deterioration. Z Lebensm Unters Forsch. 206:29-32 (1998).

28 Bligh E and Dyer W, A rapid method of total lipid extraction and purification. Can J Biochem Physiol 37:911-917 (1959).

29 Aubourg S, Medina I, Pérez-Martín R, A comparison between conventional and fluorescence detection methods of cooking-induced damage to tuna fish lipids. $Z$ Lebensm Unters Forsch 200:252-255 (1995). 
30 Aubourg S and Medina I, Quality differences assessment in canned sardine (Sardina pilchardus) by detection of fluorescent compounds. J Agric Food Chem 45:3617-3621 (1997).

31 Statsoft. Statistica for Macintosh; Statsoft and its licensors. Tulsa, Oklahoma (USA) (1994).

32 Glantz S and Slinker B, Primer of applied regression and analysis of variance. Mc Graw-Hill, New York (USA) (1990).

33 Davies $\mathrm{H}$ and Reece P, Fluorescence of fish muscle: causes of change occurring during frozen storage. J Sci Food Agric 33:1143-1151 (1982).

34 Kikugawa K and Beppu M, Involvement of lipid oxidation products in the formation of fluorescent and cross-linked proteins. Chem Phys Lipids 44:277-297 (1987).

35 Gardner H, Lipid hydroperoxide reactivity with proteins and amino acids: A review. J Agric Food Chem 27:220-229 (1979).

36 Pokorný J, Browning from lipid-protein interactions. Prog Food Nutrit Sci 5:421$428(1981)$.

37 Fieser L and Fieser M, Química Orgánica Superior. Ediciones Grijalbo, S A, Barcelona (Spain), p 481 (1966).

38 Allinger N, Cava M, de Jongh D, Johnson C, Lebel N and Stevens C, Química Orgánica. Editorial Reverté, S A, Barcelona (Spain), p 545 (1978).

39 King F, Anderson M and Steinberg M, The effect of linoleic and linolenic acids on the solubility of cod actomyosin. J Food Sci 27:363-366 (1962).

40 Jarenback L and Liljemark A, Ultrastructural changes during storage of cod. III. Effect of linoleic acid and linolenic acid hydroperoxides on myofibrillar proteins. J Food Technol 10:437-452 (1975). 


\section{FIGURE LEGENDS}

$\underline{\text { Figure 1: }}$ Fluorescence ratio $(\delta \mathrm{F})$ values* obtained by reaction at $30^{\circ} \mathrm{C}$ of cod liver oil (CLO) with propylamine in the presence of fatty acids $(0.6 \mathrm{mM})$ with different chain length **

* Initial $\delta \mathrm{F}$ value of CLO was 2.43 \pm 0.19 .

** Fatty acids abbreviations: LA (lauric), MA (myristic), PA (palmitic), SA (stearic) and AA (arachidic).

Figure 2: Fluorescence ratio $(\delta \mathrm{F})$ values* obtained by reaction at $-10^{\circ} \mathrm{C}$ of cod liver oil (CLO) with propylamine in the presence of fatty acids $(0.6 \mathrm{mM})$ with different chain length **

* Initial $\delta \mathrm{F}$ value of CLO was 2.43 \pm 0.19 .

** Fatty acids abbreviations as specified in Figure 1.

Figure 3: Fluorescence ratio $(\delta \mathrm{F})$ values* obtained by reaction at $30^{\circ} \mathrm{C}$ of cod liver oil (CLO) with propylamine in the presence of fatty acids $(0.6 \mathrm{mM})$ with different degree of unsaturation ** 
* Initial $\delta F$ value of CLO was 2.43 \pm 0.19 .

** Fatty acids abbreviations: SA (stearic), OA (oleic), LnA (linoleic) and LnnA (linolenic).

Figure 4: Fluorescence ratio $(\delta \mathrm{F})$ values* obtained by reaction at $-10^{\circ} \mathrm{C}$ of cod liver oil (CLO) with propylamine in the presence of fatty acids $(0.6 \mathrm{mM})$ with different degree of unsaturation $* *$

* Initial $\delta F$ value of CLO was 2.43 \pm 0.19 .

** Fatty acids abbreviations as specified in Figure 3.

Figure 5: Fluorescence ratio $(\delta \mathrm{F})$ values obtained in the fish (hake and pout) muscle systems at $30^{\circ} \mathrm{C}$ in the presence/absence of myristic acid (MA; $1.00 \%$, w/w)

* Initial fish muscle $\delta F$ values: $0.78 \pm 0.06$ (hake) and $0.98 \pm 0.10$ (pout). 


\section{TABLE 1}

Fluorescence ratio $(\delta \mathrm{F})$ values* obtained by reaction at $30^{\circ} \mathrm{C}$ of cod liver oil (CLO) with propylamine (Pam) in the presence of different myristic acid (MA) concentrations**

REACTION TIME (days)

\begin{tabular}{|c|c|c|c|c|c|}
\hline $\begin{array}{c}\text { Reaction } \\
\text { Mixture }\end{array}$ & $\mathbf{1}$ & $\mathbf{3}$ & $\mathbf{7}$ & $\mathbf{1 4}$ & $\mathbf{2 5}$ \\
\hline Blank & $3.33 \mathrm{a}$ & $4.74 \mathrm{a}$ & $7.38 \mathrm{a}$ & $10.54 \mathrm{a}$ & $13.97 \mathrm{a}$ \\
\hline $\mathrm{MA}_{1}$ & $3.57 \mathrm{ab}$ & $5.12 \mathrm{ab}$ & $8.25 \mathrm{ab}$ & $11.78 \mathrm{abc}$ & $14.86 \mathrm{ab}$ \\
\hline $\mathrm{MA}_{2}$ & $3.71 \mathrm{ab}$ & $4.92 \mathrm{ab}$ & $7.96 \mathrm{ab}$ & $11.30 \mathrm{ab}$ & $14.77 \mathrm{ab}$ \\
\hline $\mathrm{MA}_{3}$ & $3.81 \mathrm{~b}$ & $5.75 \mathrm{bc}$ & $9.39 \mathrm{bc}$ & $13.05 \mathrm{bc}$ & $16.73 \mathrm{bc}$ \\
\hline $\mathrm{MA}_{4}$ & $3.92 \mathrm{bc}$ & $5.97 \mathrm{~cd}$ & $9.58 \mathrm{c}$ & $13.51 \mathrm{c}$ & $17.25 \mathrm{~cd}$ \\
\hline $\mathrm{MA}_{5}$ & $4.29 \mathrm{c}$ & $6.56 \mathrm{~d}$ & $10.58 \mathrm{c}$ & $15.84 \mathrm{~d}$ & $19.10 \mathrm{~d}$ \\
\hline
\end{tabular}

* Values in the same column followed by different letters are significantly different $(\mathrm{p}<0.05)$. Initial $\delta \mathrm{F}$ value of CLO was $2.37 \pm 0.13$.

** Five different MA/CLO ratios (w/w) were checked: $\mathrm{MA}_{1}(0.01 \%), \mathrm{MA}_{2}(0.03 \%)$, $\mathrm{MA}_{3}(0.10 \%), \mathrm{MA}_{4}(0.30 \%)$ and $\mathrm{MA}_{5}(1.00 \%)$. 


\section{TABLE 2}

Fluorescence ratio $(\delta \mathrm{F})$ values* obtained by reaction of cod liver oil (CLO) with propylamine (Pam) in the presence of myristic acid (MA) at different temperatures**

\begin{tabular}{|c|c|c|c|c|}
\hline $\begin{array}{c}\text { Reaction } \\
\text { Mixture }\end{array}$ & Time (days) & $\mathbf{1 5}^{\circ} \mathbf{C}$ & $\mathbf{3 0 ^ { \circ } \mathbf { C }}$ & $\mathbf{5 5 ^ { \circ } \mathbf { C }}$ \\
\hline Blank & 1 & $2.81 \mathrm{a}$ & $3.33 \mathrm{a}$ & $5.33 \mathrm{~b}$ \\
\hline Blank & 3 & $3.23 \mathrm{a}$ & $4.74 \mathrm{~b}$ & $7.92 \mathrm{c}$ \\
\hline Blank & 7 & $4.58 \mathrm{a}$ & $7.38 \mathrm{~b}$ & $11.19 \mathrm{c}$ \\
\hline Blank & 14 & $6.35 \mathrm{a}$ & $10.54 \mathrm{~b}$ & $16.18 \mathrm{c}$ \\
\hline Blank & 25 & $8.55 \mathrm{a}$ & $13.97 \mathrm{~b}$ & $22.43 \mathrm{c}$ \\
\hline MA $_{5}$ & 1 & $3.08 \mathrm{a}$ & $4.29 \mathrm{~b}$ & $7.99 \mathrm{c}$ \\
\hline MA $_{5}$ & 3 & $4.11 \mathrm{a}$ & $6.56 \mathrm{~b}$ & $11.05 \mathrm{c}$ \\
\hline $\mathrm{MA}_{5}$ & 7 & $6.45 \mathrm{a}$ & $10.58 \mathrm{~b}$ & $15.15 \mathrm{c}$ \\
\hline $\mathrm{MA}_{5}$ & 14 & $10.02 \mathrm{a}$ & $15.84 \mathrm{~b}$ & $20.67 \mathrm{c}$ \\
\hline $\mathrm{MA}_{5}$ & 25 & $14.31 \mathrm{a}$ & $19.10 \mathrm{~b}$ & $27.46 \mathrm{c}$ \\
\hline
\end{tabular}

* Values in the same row followed by different letters are significantly different $(\mathrm{p}<0.05)$. Initial $\delta \mathrm{F}$ value of CLO was $2.37 \pm 0.13$.

** MA was employed in the $1.00 \% \mathrm{MA} / \mathrm{CLO}$ ratio (w/w; MA 5 ; Table 1). 


\section{TABLE 3}

Correlation coefficients* between the fluorescence ratio value and the reaction time for two reaction mixtures tested at different temperatures**

\begin{tabular}{|c|c|c|c|}
\hline Reaction Mixture & $\mathbf{1 5}^{\mathbf{0}} \mathbf{C}$ & $\mathbf{3 0}^{\mathbf{}} \mathbf{C}$ & $\mathbf{5 5}^{\mathbf{}} \mathbf{C}$ \\
\hline Blank & 0.996 & 0.986 & 0.993 \\
\hline $\mathrm{MA}_{5}$ & 0.996 & 0.967 & 0.989 \\
\hline
\end{tabular}

* Significant values $(\mathrm{p}<0.05)$ were obtained in all cases.

** Abbreviations as specified in Table 1 . 


\section{TABLE 4}

Fluorescence ratio $(\delta \mathrm{F})$ values* obtained by reaction at $30^{\circ} \mathrm{C}$ of cod liver oil (CLO) with propylamine (Pam) in the presence of different chain length fatty acids**

TIME (days)

\begin{tabular}{|c|c|c|c|c|c|}
\hline $\begin{array}{l}\text { Reacting } \\
\text { Mixture }\end{array}$ & 1 & 3 & 7 & 14 & 25 \\
\hline CLO & $2.66 \mathrm{a}$ & $2.50 \mathrm{a}$ & $2.53 \mathrm{a}$ & $2.62 \mathrm{a}$ & $2.84 \mathrm{a}$ \\
\hline $\mathrm{CLO}+\mathrm{Pam}$ & $3.45 \mathrm{~b}$ & $4.97 \mathrm{~b}$ & $7.74 \mathrm{~b}$ & $10.32 \mathrm{~b}$ & $13.77 \mathrm{~b}$ \\
\hline $\begin{array}{l}\mathrm{CLO}+\mathrm{Pam} \\
\quad+\mathrm{LA}\end{array}$ & $4.37 \mathrm{~d}$ & $6.39 \mathrm{~d}$ & $10.83 \mathrm{~d}$ & $14.77 \mathrm{~d}$ & $19.24 \mathrm{~d}$ \\
\hline $\begin{array}{c}\mathrm{CLO}+\mathrm{Pam} \\
+\mathrm{MA}\end{array}$ & $4.29 \mathrm{~d}$ & $6.27 \mathrm{~d}$ & $10.82 \mathrm{~d}$ & $14.65 \mathrm{~d}$ & $19.02 \mathrm{~d}$ \\
\hline $\begin{array}{l}\mathrm{CLO}+\mathrm{Pam} \\
+ \text { PA }\end{array}$ & $4.16 \mathrm{~cd}$ & $6.05 \mathrm{~cd}$ & $10.12 \mathrm{~cd}$ & $13.99 \mathrm{~cd}$ & $17.93 \mathrm{~cd}$ \\
\hline $\begin{array}{c}\text { CLO + Pam } \\
+ \text { SA }\end{array}$ & $3.94 \mathrm{c}$ & 5.60 bc & $9.43 \mathrm{c}$ & $13.20 \mathrm{c}$ & $17.41 \mathrm{c}$ \\
\hline $\begin{array}{c}\mathrm{CLO}+\mathrm{Pam} \\
+ \text { AA }\end{array}$ & 3.89 с & $6.09 \mathrm{~cd}$ & $9.67 \mathrm{c}$ & $13.64 \mathrm{~cd}$ & 16.99 с \\
\hline
\end{tabular}

* Values in the same column followed by different letters are significantly different $(\mathrm{p}<0.05)$. Initial $\delta \mathrm{F}$ value of CLO was $2.43 \pm 0.19$.

** Fatty acids abbreviations: LA (lauric), MA (myristic), PA (palmitic), SA (stearic) and AA (araquidic). All FFA were employed at the same concentration (6 mM). 


\section{TABLE 5}

Fluorescence ratio $(\delta \mathrm{F})$ values* obtained by reaction at $30^{\circ} \mathrm{C}$ of cod liver oil (CLO) with propylamine (Pam) in the presence of different unsaturation degree fatty acids**

TIME (days)

\begin{tabular}{|c|c|c|c|c|c|}
\hline $\begin{array}{l}\text { Reacting } \\
\text { Mixture }\end{array}$ & 1 & 3 & 7 & 14 & 25 \\
\hline CLO & $2.66 \mathrm{a}$ & $2.50 \mathrm{a}$ & $2.53 \mathrm{a}$ & $2.62 \mathrm{a}$ & $2.84 \mathrm{a}$ \\
\hline $\mathrm{CLO}+\mathrm{Pam}$ & $3.45 \mathrm{~b}$ & $4.97 \mathrm{~b}$ & $7.74 \mathrm{~b}$ & $10.32 \mathrm{~b}$ & $13.77 \mathrm{~b}$ \\
\hline $\begin{array}{l}\mathrm{CLO}+\mathrm{Pam} \\
\quad+\mathrm{SA}\end{array}$ & $3.94 \mathrm{c}$ & 5.60 bc & $9.43 \mathrm{c}$ & $13.20 \mathrm{c}$ & $17.41 \mathrm{c}$ \\
\hline $\begin{array}{l}\mathrm{CLO}+\mathrm{Pam} \\
\quad+\mathrm{OA}\end{array}$ & $4.04 \mathrm{C}$ & $6.06 \mathrm{~cd}$ & $10.26 \mathrm{~cd}$ & $14.65 \mathrm{~cd}$ & $18.52 \mathrm{~cd}$ \\
\hline $\begin{array}{l}\mathrm{CLO}+\mathrm{Pam} \\
+ \text { LnA }\end{array}$ & $4.20 \mathrm{c}$ & $6.75 \mathrm{~d}$ & 11.23 de & 16.09 de & $21.45 \mathrm{de}$ \\
\hline $\begin{array}{c}\mathrm{CLO}+\mathrm{Pam} \\
+ \text { LnnA }\end{array}$ & $4.30 \mathrm{C}$ & $6.56 \mathrm{~d}$ & $12.46 \mathrm{e}$ & $16.62 \mathrm{e}$ & 22.79 e \\
\hline
\end{tabular}

* Values in the same column followed by different letters are significantly different $(\mathrm{p}<0.05)$. Initial $\delta F$ value of CLO was $2.43 \pm 0.19$.

** Fatty acids abbreviations: SA (stearic), OA (oleic), LnA (linoleic) and LnnA (linolenic). All FFA were employed at the same concentration (6 mM). 


\section{FIGURE LEGENDS}

Figure 1: Fluorescence ratio $(\delta \mathrm{F})$ values obtained in the lean fish (hake and bib) muscle systems at $30^{\circ} \mathrm{C}$ in the presence/absence of myristic acid (MA; $1.00 \%$, w/w).

* Initial fish muscle $\delta$ F values: $0.78 \pm 0.06$ (hake) and $0.98 \pm 0.10$ (bib).

Figure 2: Fluorescence ratio $(\delta \mathrm{F})$ values obtained in the fatty fish (horse mackerel, $\mathrm{Hmac}$; sardine, Sard) muscle systems at $30^{\circ} \mathrm{C}$ in the presence/absence of myristic acid (MA; 1\%, w/w).

* Initial fish muscle $\delta \mathrm{F}$ values: $0.89 \pm 0.06$ (horse mackerel) and $0.79 \pm 0.05$ (sardine). 